\title{
Alternative splicing of $\beta$-tropomyosin pre-mRNA: cis-acting elements and cellular factors that block the use of a skeletal muscle exon in nonmuscle cells
}

\author{
Wei Guo, ${ }^{1,2}$ George J. Mulligan, ${ }^{1,3}$ Steven Wormsley, ${ }^{1}$ and David M. Helfman ${ }^{1,4}$ \\ ${ }^{1}$ Cold Spring Harbor Laboratory, Cold Spring Harbor, New York 11724 USA; ${ }^{2}$ Department of Biochemistry and Cell Biology, \\ ${ }^{3}$ Cellular and Developmental Biology Graduate Program, State University of New York at Stony Brook, Stony Brook, \\ New York 11790 USA
}

\begin{abstract}
The rat $\beta$-tropomyosin ( $\beta$-TM) gene encodes both skeletal muscle $\beta$-TM and fibroblast TM-1 by an alternative RNA-splicing mechanism. This gene contains 11 exons. Exons 1-5, 8, and 9 are common to all mRNAs expressed from the gene. Exons 6 and 11 are used in fibroblasts as well as smooth muscle cells, whereas exons 7 and 10 are used in skeletal muscle cells. In this study we have carried out an extensive mutational analysis to identify cis-acting elements that block the use of the skeletal muscle-specific exon 7 in nonmuscle cells. These studies localize the critical elements for regulated alternative splicing to sequences within exon 7 and the adjacent upstream intron. In addition, mutations that inactivate the $5^{\prime}$ - or $3^{\prime}$-splice sites of exon 6 do not result in the use of the skeletal muscle-specific exon 7 in nonmuscle cells, suggesting that splice-site selection in vivo is not regulated by a simple cis-acting competition mechanism but, rather, by a mechanism that inhibits the use of exon 7 in certain cellular environments. In support of this hypothesis we have identified sequence-specific RNA-binding proteins in HeLa cell nuclear extracts using native gel electrophoresis and binding competition assays. Mutations in the pre-mRNA that result in the use of the skeletal muscle exon in vivo also disrupt the binding of these proteins to the RNA in vitro. We propose that the binding of these proteins to the pre-mRNA is involved in regulated alternative splicing and that this interaction is required for blocking the use of the skeletal muscle exon in nonmuscle cells.
\end{abstract}

[Key Words: $\beta$-Tropomyosin gene; alternative splicing; RNA processing]

Received June 26, 1991; revised version accepted September 12, 1991.

Alternative RNA splicing is a fundamental process in eukaryotes that contributes to tissue-specific and developmentally regulated patterns of gene expression (Smith et al. 1989; McKeown 1990). At present, relatively little is known about the cellular factors and mechanisms that are responsible for the selection of alternative splice sites in complex transcription units and how the splicing signals in alternatively spliced exons differ from those in constitutively spliced exons (for review, see Smith et al. 1989; McKeown 1990; Maniatis 1991). Significant progress has been made in Drosophila systems such as in the genes of the sex-determination pathway, suppressor of white apricot and Drosophila P-transposase. In these systems alternative splicing is subject to regulation by factors that either inhibit or activate the use of alternative $5^{\prime}$ - or 3'-splice sites (McKeown 1990; Hedley and Maniatis 1991; Maniatis 1991). In contrast, in vertebrate systems, much less is known about the mechanisms and

${ }^{4}$ Corresponding author. cellular factors involved in regulated alternative splicing, but a number of features in the pre-mRNA have been implicated in alternative splice-site selection. These include the relative strengths of $5{ }^{\prime}$ - and $3^{\prime}$ - splice sites (Zhuang et al. 1987; Kuo et al. 1991; Mullen et al. 1991), intron size (Fu and Manley 1987), the pyrimidine content of a 3'-splice site (Fu et al. 1988; Mullen et al. 1991), the location of branchpoints (Gattoni et al. 1988; Helfman and Ricci 1989; Smith and Nadal-Ginard 1989; Goux-Pelletan et al. 1990; Helfman et al. 1990), multiple alternative branchpoints (Noble et al. 1987, 1988; Gattoni et al. 1988; Helfman and Ricci 1989), branchpoint sequences (Reed and Maniatis 1988; Zhuang et al. 1989; Mullen et al. 1991), intron sequences between a 3'-splice site and upstream branchpoint (Goux-Pelletan et al. 1990; Helfman et al. 1990; Libri et al. 1990), and exon sequences (Reed and Maniatis 1986; Mardon et al. 1987; Somaseker and Mertz 1985; Helfman et al. 1988; Cooper and Ordahl 1989; Hampson et al. 1989; Streuli and Saito 1989; Black 1991; Libri et al. 1990, 1991).

In addition to cis-acting elements in the pre-mRNA, at 
least one cellular factor isolated from mammalian cells, termed ASF (alternative splicing factor) or SF2, has been found to affect the choice of alternative $5^{\prime}$-splice sites (Ge and Manley 1990; Krainer et al. 1990a). In vitro splicing studies with the early region of simian virus (SV40) involving the large $\mathrm{T}$ - and small $\mathrm{t}$-splice choices, and model pre-mRNA substrates derived from the human $\beta$-globin gene demonstrated that high concentrations of ASF/SF2 promote the use of proximal $5^{\prime}$-splice sites, whereas low concentrations favor the use of distal $5^{\prime}$ splice sites (Ge and Manley 1990; Krainer et al. 1990a). Although this factor is also required for general splicing (Krainer et al. 1990b), differences in the relative concentrations or activities of this factor in different cell types could, in principle, play a role in regulated alternative splicing.

The tropomyosin genes represent an excellent system to study the molecular basis for tissue-specific RNA splicing. Tropomyosins are a diverse group of actin-binding proteins found in all eukaryotic cells, with distinct isoforms found in muscle (skeletal, cardiac, and smooth), brain, and various nonmuscle cells. In many animals, such as nematodes, flies, frogs, birds, and mammals, this isoform diversity is generated by a combination of multiple genes, most of which exhibit alternative splicing of primary RNA transcripts (for review, see Lees-Miller and Helfman 1991). We have been using the rat $\beta$-tropomyosin ( $\beta$-TM) gene as a model system to investigate the mechanisms responsible for developmental and tissuespecific alternative RNA splicing (Helfman et al. 1986, 1988, 1990; Helfman and Ricci 1989|. This gene spans 10 $\mathrm{kb}$ of DNA with 11 exons and encodes two distinct isoforms, namely skeletal muscle $\beta$-TM and fibroblast tropomyosin-1 (TM-1). Exons 1-5, 8, and 9 are common to all mRNAs expressed from this gene. Exons 6 and 11 are used in fibroblasts, as well as in smooth muscle, whereas exons 7 and 10 are used exclusively in skeletal muscle. Our previous studies of tropomyosin pre-mRNA splicing with HeLa cell (nonmuscle) systems revealed an ordered pathway of splicing in which either of the internal alternatively spliced exons (exon 6 or 7) must first be joined to the downstream common exon before they can be spliced to the upstream common exon (Helfman et al. 1988). Unlike most branchpoints that have been mapped, in which a single adenosine residue located 1840 nucleotides from a 3 '-splice site is used during lariat formation (Green 1986), in vitro splicing of exon 5 to exon 7 (skeletal muscle-type splice) involved the use of multiple branchpoints that are located an unusually long distance $(144,147$, and 153 nucleotides) from the 3'splice site of exon 7 (Helfman and Ricci 1989). Subsequently, we investigated the functional role of the intron sequences between the distant branchpoints and the $3^{\prime}$ splice site of the skeletal muscle exon 7. Our results demonstrated that two distinct functional elements are present in this region (Helfman et al. 1990). The first element is comprised of a polypyrimidine tract located 89-143 nucleotides upstream of the 3'-splice site, which specifies the location of the branchpoints used, 144-153 nucleotides upstream of exon 7 . The second element is comprised of intron sequences located between the polypyrimidine tract and the $3^{\prime}$-splice site of exon 7 . This region contains an important determinant in alternative splice site selection because deletion of these sequences results in the use of the skeletal muscle-specific exon in nonmuscle cells (Helfman et al. 1990).

To study further how these sequences prevent the use of exon 7 in nonmuscle cells, we carried out an extensive mutational analysis of the intron sequences upstream and downstream of exon 7 , as well within the exon itself. These studies show that the critical cis-acting elements for regulated alternative splicing are confined to sequences within exon 7 and the adjacent upstream intron. We also demonstrate that these sequences function, in part, to regulate splice-site selection in vivo by interacting with cellular factors and thereby block the use of the skeletal muscle exon in nonmuscle cells.

\section{Results}

\section{Nucleotide substitutions within intron 6 result in use of the skeletal muscle-specific exon 7 in nonmuscle cells}

To localize further the cis-acting elements involved in splice site selection, we constructed a series of minigenes containing clustered point mutations in intron 6 (Fig. 1). These mutations do not alter the distance between the $3^{\prime}$-splice site of exon 7 and the upstream branchpoints, and result in only 3-5 nucleotide substitutions. This approach was chosen to determine whether the deletion mutations, which resulted in the use of the skeletal muscle-type splice in nonmuscle cells, altered splice site selection by simply altering the distance between the 3'-splice site and upstream branchpoints or by removing specific inhibitory sequences (Helfman et al. 1990). The sequence of intron 6 and the positions of the substitutions in this intron are indicated in Figure 1. The mutations were introduced into plasmid pSV40-2 for in vivo analyses (Helfman et al. 1988, 1990). Plasmid pSV40-2 carries a minigene consisting of the SV40 early promoter and a functional poly(A) site flanking genomic tropomyosin sequences. We have demonstrated previously that transient expression of wild-type plasmid pSV40-2 in HeLa cells resulted in spliced RNA that contains exons $5+6+8+9$ and very little detectable levels of spliced RNA containing the skeletal muscle-type splice products, that is, exons $5+7+8+9$ (Helfman et al. 1988, 1990). HeLa cells were transfected with the wild-type and six clustered point mutation plasmids (int-1 through int-6), and $48 \mathrm{hr}$ later the cytoplasmic RNA was isolated and analyzed by RNase protection. The RNase protection analyses of these RNAs and of RNA isolated from mock-infected cells were carried out with RNA probes derived from cDNA clones encoding rat fibroblast TM- 1 and skeletal muscle $\beta$-TM (Fig. 2A). Transient expression of the wild-type plasmid pSV40-2 in HeLa cells resulted in spliced RNA that contains exons $5+6+8+9$. Only low levels of the skeletal muscle-type splice with the wild-type construct, that is, ex- 


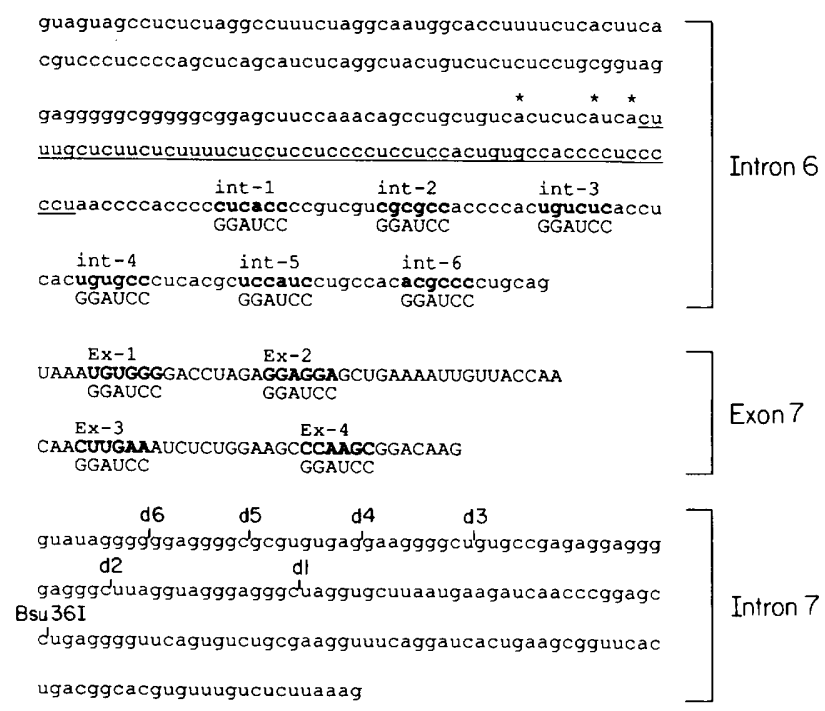

Figure 1. Nucleotide sequence of substitutions and mutations within the $\beta$-TM pre-mRNA. The nucleotide sequence of intron 6 , exon 7 , and intron 7 , respectively, are shown. The positions of the lariat branchpoints used in splicing exon 5 to exon 7 , which are located 144, 147, and 153 nucleotides upstream of exon 7 are indicated $(*)$. The 55-nucleotide-long polypyrimidine tract located 89-143 nucleotides upstream from the 3 '-splice site of exon 7 is underlined. Nucleotide substitutions in intron 6 and exon 7, which introduced a BamHI site, are indicated int-1 through int- 6 for mutations in the 3 ' end of intron 6 and Ex-1 through Ex-4 for mutations in exon 7. (d1-d6) Deletions in intron 7, beginning at a Bsu36I site located 75 bases upstream of exon 8 , and going toward the $5^{\prime}$ end of intron 7 .

ons $5+7+8+9$, were detected (Fig. 2A, lane labeled W). In contrast, transient expression of the minigenes containing the mutations designated int- 2 through int -5 resulted in expression of two forms of spliced RNA: one containing exons $5+6+8+9$, and the other containing exons $5+7+8+9$ (skeletal muscle-type splice) (Fig. 2A). On the other hand, transient expression of mutants int- 1 and int 6 resulted in spliced RNA containing mainly exons $5+6+8+9$. We also determined the effects of deleting sequences between some of the clustered point mutations. Thus, three mutant plasmids were constructed, designated int $3-5$, int $2-5$, and int $1-6$, which contain deletions between the corresponding clustered point mutations shown in Figure 1. These constructs were tested in vivo by cloning the corresponding deletions into plasmid pSV40-2 (Helfman et al. 1988, 1990|. HeLa cells were transfected with the wild-type and three deletion mutants, and $48 \mathrm{hr}$ later the cytoplasmic RNA was isolated and analyzed by RNA protection (Fig. 2B). Transient expression of the wild-type plasmid pSV40-2 in HeLa cells resulted in spliced RNA that contains exons $5+6+8+9$. There was no skeletal muscle-type splice with the wild-type construct, that is, exons $5+7+8+9$. In contrast, transient expression of the minigenes containing the three mutations resulted predominately in spliced RNA containing exons $5+7+8+9$ (skeletal muscle-type splice) (Fig. 2B).
These results indicate that specific sequences in the $3^{\prime}$ end of intron 6 are involved in blocking the use of exon 7 in HeLa cells.

\section{Nucleotide substitutions within the skeletal muscle-specific exon 7 also result in the use of exon 7 in nonmuscle cells}

To analyze the role of sequences contained within exon 7 we introduced a series of clustered point mutations into four separate regions of the skeletal muscle exon. The sequence of exon 7 and the position of the exon substitutions are indicated in Figure 1. The substitutions were introduced into plasmid pSV40-2 for in vivo analyses (Fig. 3). HeLa cells were transfected with the wildtype and four mutant plasmids (Ex-1 through Ex-4) and analyzed as described above. Because the clustered point mutations introduce regions of noncomplementarity to the wild-type cDNA probe encoding the skeletal muscle RNA, the protected fragments are digested at an internal position. The positions of the two protection fragments resulting from splicing of exons $5+7+8+9$ are indicated in Figure 3. The Ex-1 mutation, which alters 5 nucleotides near the 5' end of exon 7, was the strongest activating exon mutation, resulting in spliced RNA containing the skeletal muscle-type splice and no detectable levels of spliced RNA containing exon 6 (Fig. 3). The other mutations within exon 7 resulted in different levels of activation of the skeletal muscle-type splice. These results indicate that cis-acting elements necessary for tissue-specific splicing are also contained within exon 7 .

Sequences downstream of exon 7 do not affect alternative splice-site selection in nonmuscle cells

We and others have suggested previously that sequences contained within exon 7, as well as upstream and downstream intron sequences, might form an RNA secondary structure that prevents the use of this exon in nonmuscle cells (Helfman et al. 1988, 1990; Libri et al. 1989, 1990). To determine whether specific sequences within intron 7 are required for regulating the use of exon 7 in nonmuscle cells we introduced a series of deletions in this intron (Fig. 1). The deletions were introduced into plasmid pSV40-2 for in vivo analyses (Fig. 4). Transient expression of the wild-type and six mutant plasmids in HeLa cells resulted in spliced RNA that contains exons $5+6+8+9$ and almost undetectable levels of the skeletal muscle-type spliced RNA (Fig. 4). In no case did we observe activation of the skeletal muscle exon with any of the deletions tested. These results demonstrate that intron sequences downstream of exon 7 do not play a role in the regulation of alternative splice-site selection of this exon in nonmuscle cells.

\section{Inactivation of exon 6 does not result in increased use of the skeletal muscle-specific exon 7 in nonmuscle cells}

We then determined whether alternative splicing is due to a simple cis-acting competition for splice sites. For 
A

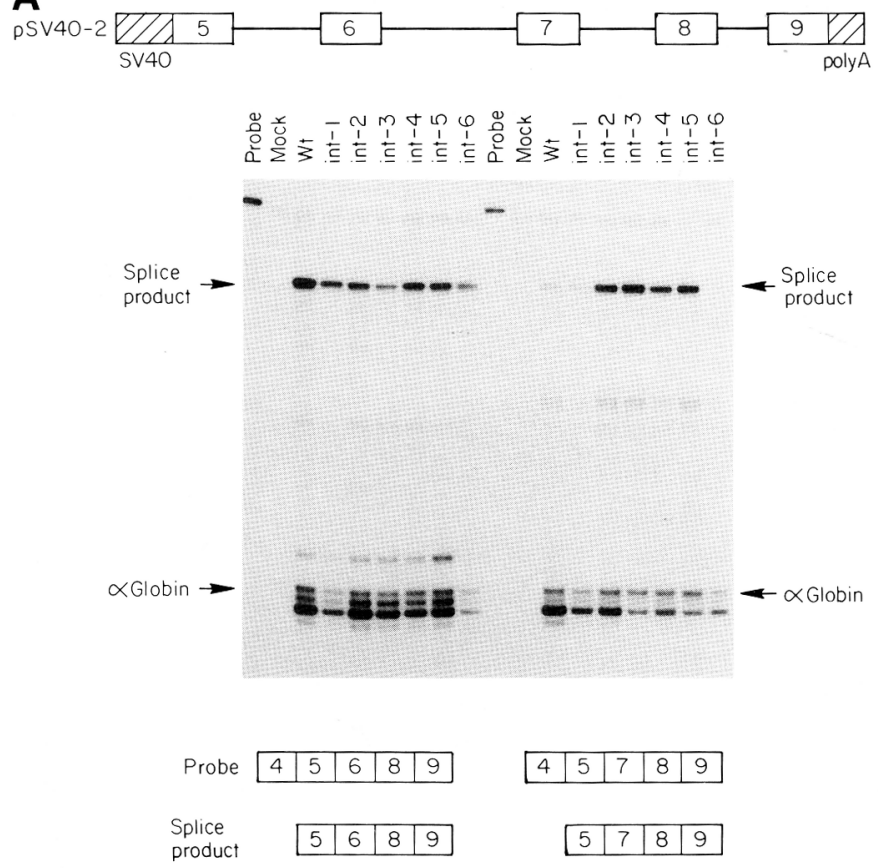

B
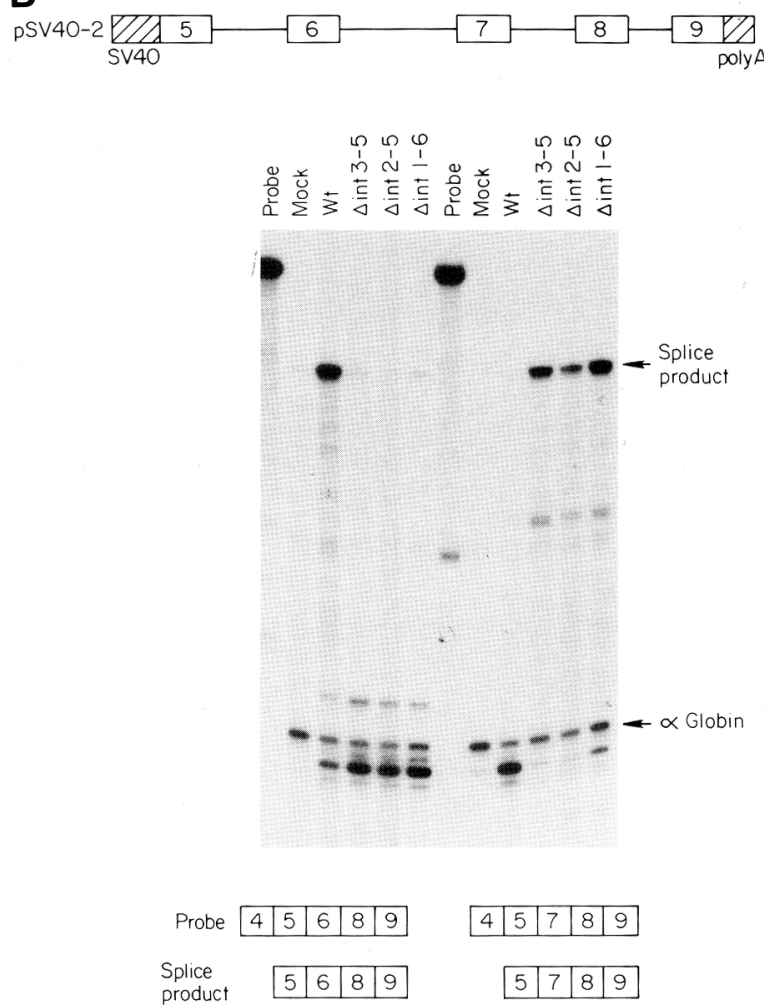

Figure 2. (A) Nucleotide substitutions within intron 6 result in the use of the skeletal muscle-specific exon (exon 7) in nonmuscle cells. Clustered point mutations where introduced into six regions of intron 6 (indicated int-1 through int-6; see also Fig. 1). (Top) Schematic diagram of the tropomyosin minigene used in the HeLa cell transfection. (Middle) Autoradiographs of RNA protection analyses with cDNA probes derived from cDNA clones encoding rat fibroblast TM-1 (left) and skeletal muscle $\beta$-TM (right). The band corresponding to the reference $\alpha$-globin RNAs is labeled. The identity of the band just below the $\alpha$-globin protection products likely represents the protection of sequences containing exons $8+9$. (Bottom) Schematic diagram of the structure of the RNA probe and protected fragments (splice products). It is worth noting that because both exon 6 and exon 7 each contain 76 nucleotides, the splice products resulting from the use of each exon are the same number size. (B). Deletions in intron 6 result in the use of exon 7 in nonmuscle cells. Mutations were constructed in the 3' end of intron 6 by deleting the sequences between the given clustered point mutations shown in Fig.1. Schematic diagram of the tropomyosin minigenes used and autoradiographs of RNA protection analyses are as described in $A$.

example, if exon 6 splice junctions are intrinsically more efficient than those of exon 7 in nonmuscle cells, then inactivating the competing splice sites should result in increased use of the skeletal splice in HeLa cells. To test this hypothesis, a series of deletions and point mutations were introduced into the $5^{\prime}$ - and $3^{\prime}$-splice sites of exon 6 (Fig. 5). The $5^{\prime}$-splice site of exon 6 was either deleted by removing the $\mathrm{Ncol} / \mathrm{StuI}$ fragment containing the $3^{\prime}$ end of exon 6 and 17 nucleotides of downstream intron, or inactivated by two point mutations that changed the conserved GT dinucleotide to GA or AT. Similarly, the $3^{\prime}$-splice site of exon 6 was either deleted by removing the MstII/NcoI fragment containing 100 nucleotides of upstream intron and the $5^{\prime}$ end of exon 6 , or inactivated by a point mutation that changed the conserved AG dinucleotide to CG. The substitutions were introduced into plasmid pSV40-2 for in vivo analyses (Fig. 5). As expected, transient expression of the wild-type plasmid pSV40-2 in HeLa cells resulted in spliced RNA that contains exons $5+6+8+9$. Transient expression of the minigenes containing mutations in the $5^{\prime}$ - and $3^{\prime}$-splice sites of exon 6 resulted in virtually undetectable levels of spliced RNA containing this exon. However, in no case did we observe increased use of the skeletal muscle exon with any of the mutant constructs. These results demonstrate that the lack of use of skeletal muscle exon is not due to a simple cis-acting competition mechanism but, rather, to a mechanism that blocks the use of the skeletal muscle exon (exon 7) in nonmuscle cells.

Two different mechanisms could explain why exon 7 is excluded in nonmuscle cells. The first might involve muscle-specific factors that activate the splicing of exon 7. For example, we and others have speculated that exon 7 is sequestered in a secondary structure, which is disrupted by muscle-specific factors to permit the use of this exon (Goux-Pelletan et al. 1990; Helfman et al. 1990; D'Orval et al. 1991). The second mechanism might involve specific cellular factors that block the use of the skeletal muscle-type splice. We reasoned that if a cellular factor repressed the use of the skeletal muscle exon 

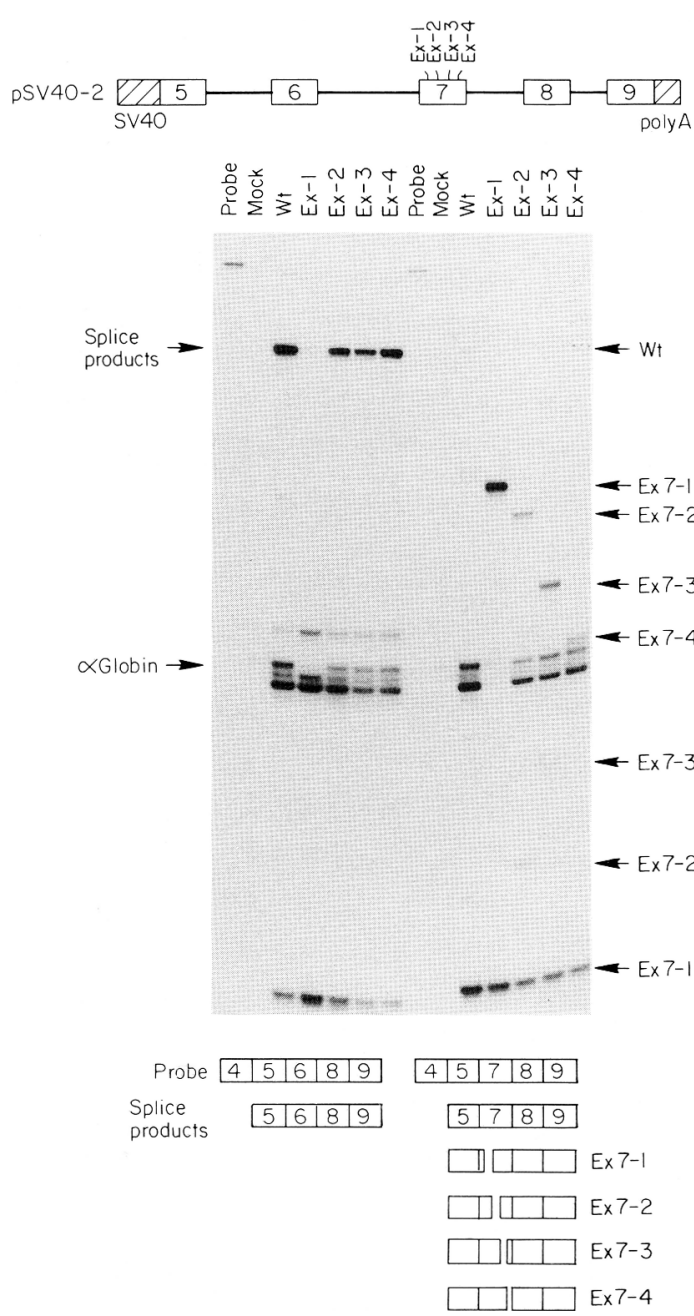

Figure 3. Sequences in exon 7 play a role in alternative splicesite selection. Clustered point mutations where introduced into four regions of exon 7 (indicated Ex-1 through Ex-4; see also Fig. 1). Schematic diagram of the tropomyosin minigenes used and autoradiographs of RNA protection analyses are as described in Fig. 2A. Because the clustered point mutations introduce regions of noncomplementarity to the wild-type cDNA probe encoding the skeletal muscle RNA, the protected fragments are digested at an internal position and their position of two resulting fragments are indicated at right (arrows).

by binding to the pre-mRNA, it might be possible to overcome this inhibition by introducing large quantities of pre-mRNA into a cell and thereby titrate the inhibitory factor. Accordingly, we transfected increasing amounts of the wild-type plasmid in HeLa cells and determined the patterns of alternatively spliced RNAs /Fig. 6). In transfections with $1.0-5.0 \mu \mathrm{g}$ of plasmid, only fully spliced RNA containing exons $5+6+8+9$ was detected. In contrast, transfection of $10-20 \mu \mathrm{g}$ of plasmid resulted in use of the skeletal muscle-type splice in HeLa cells. In addition, because our tropomyosin minigene plasmid contains an origin of replication for $\mathrm{T}$ antigen, we cotransfected $2 \mu \mathrm{g}$ of the wild-type tropomyosin minigene with a plasmid that expresses $\mathrm{T}$ antigen and thus allows amplification of the tropomyosin plasmid. As indicated in Figure 6, coexpression of $\mathrm{T}$ antigen resulted in spliced RNA containing either exon 6 or exon 7. These results provide evidence to suggest that HeLa cells contain limited amounts of factors that block the use of the skeletal muscle splice.

\section{A HeLa nuclear protein binds to the intron element that inhibits the use of the skeletal muscle-specific exon in nonmuscle cells}

Having localized the sequences in the pre-mRNA that play an important role in regulated alternative splice site selection to the $3^{\prime}$ end of intron 6 and exon 7, we then examined the ability of RNA containing these sequences to interact with factors present in nuclear extracts. We used an RNA mobility-shift assay on nondenaturing polyacrylamide gels to detect the interaction of cellular factors with the ${ }^{32} \mathrm{P}$-labeled RNA. When a wild-type RNA probe, termed Ex-7, which contains 90 nucleotides of intron sequences upstream of exon 7 , exon 7 , and 25 nucleotides of intron sequences downstream of exon 7 (see diagram in Fig. 7), was incubated with unfractionated HeLa cell nuclear extracts, bands with retarded mobility were detected. It is important to note that the con-

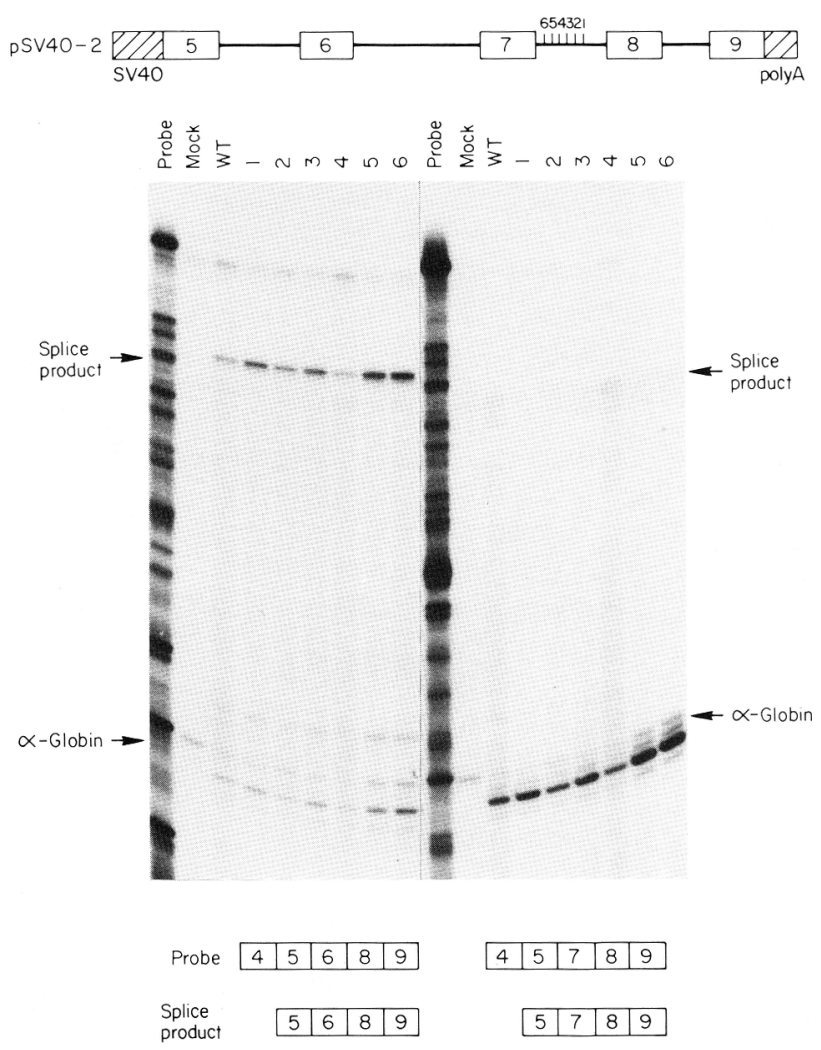

Figure 4. Deletion of sequences downstream of exon 7 does not affect alternative splice-site selection in nonmuscle cells. The positions of the deletions are shown in Fig. 1. Schematic diagram of the tropomyosin minigenes used and autoradiographs of RNA protection analyses are as described in Fig. 2A. 

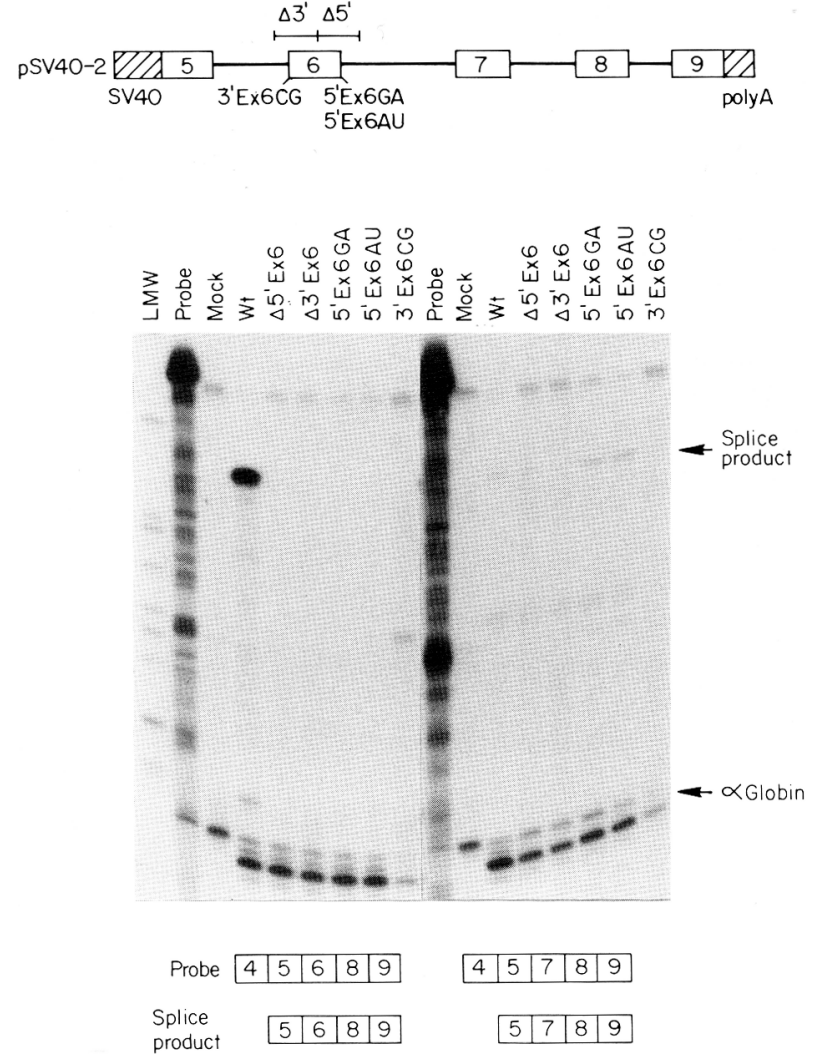

Figure 5. Inactivation of exon 6 does not lead to the use of the skeletal muscle exon in nonmuscle cells. Schematic diagram of the tropomyosin minigenes used and autoradiographs of RNA protection analyses are as described in Fig. 2A.

centration of the nuclear extract used in the gel-shift assay was a critical parameter. When the wild-type construct $(E x-7)$ was incubated with increasing amounts of nuclear extract, a band of slower mobility than free RNA was observed (Fig. 7). This complex reflects the binding of a cellular factor to the RNA. In addition, the complex was sequence specific because ${ }^{32}$ P-labeled RNAs containing a deletion at the $3^{\prime}$ end of intron $6($ int $3-5)$ did not form a complex (Fig. 7). However, at the highest concentrations of nuclear extract (lane 6) it was difficult to show specificity for wild-type versus mutant constructs because both species of RNA molecules exhibited a gel shift (Fig. 7). These results demonstrated that HeLa cell nuclear extracts contain a factor that binds to sequences at the $3^{\prime}$ end of intron 6 .

We then fractionated HeLa cell nuclear extracts with phosphocellulose and S-Sepharose column chromatography, using the gel mobility-shift assay to follow the binding activity in each fraction with the wild-type construct and the deletion mutant shown in Figure 7 (see also Materials and methods|. Fractions from the S-Sepharose column were used for all subsequent characterization of the RNA-binding activity. When the wild-type construct (Ex-7) was incubated with the partially purified fractions from the S-Sepharose column, a band of slower mobility than free RNA was observed (Fig. 8A). The complex con- tains a protein component because addition of either SDS or proteinase $\mathrm{K}$ completely eliminated complex formation (data not shown). In addition, the complex was sequence-specific because ${ }^{32} \mathrm{P}$-labeled RNAs containing regions in and around exon 6 (Ex-6 RNA) and exon 8 (Ex-8 RNA) did not form a complex (Fig. 8A). We also tested the ability of RNAs that contained deletions in the $3^{\prime}$ end of intron 6 to form a complex. Accordingly, three mutants, designated int $3-5$, int $2-5$, and int $1-6$ contain deletions between the corresponding clustered mutations shown in Figure 1. These mutations were chosen because they result in almost complete use of the skeletal muscle exon in vivo (Fig. 2B). As indicated in Figure $8 \mathrm{~A}$, all three mutations completely disrupt complex formation, indicating that these intron sequences are criti-

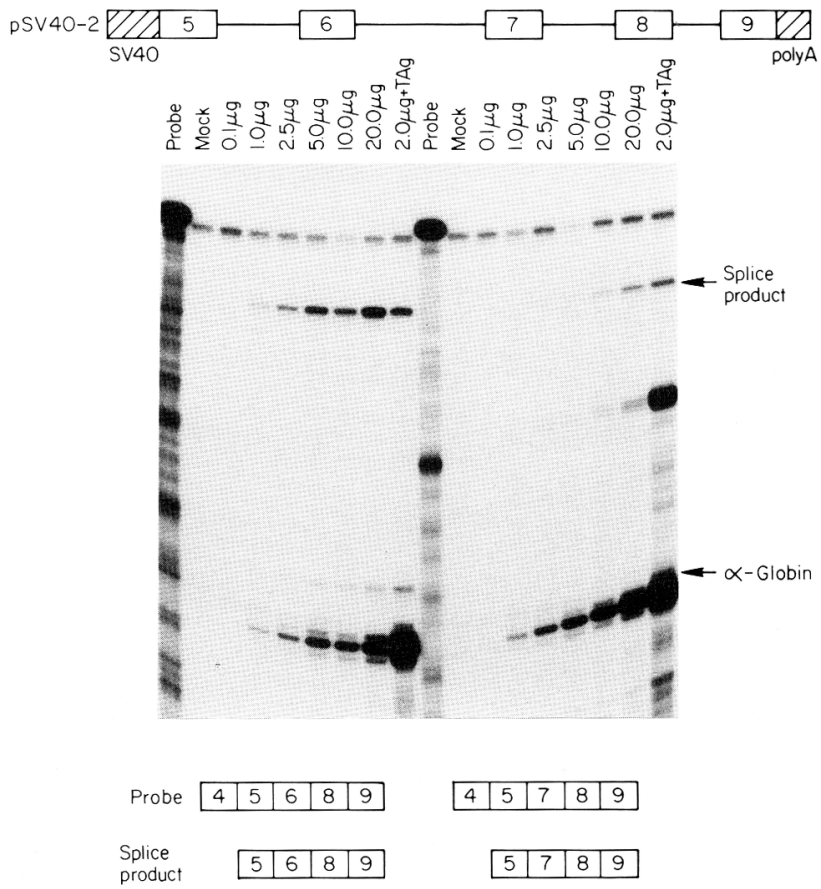

Figure 6. Transfection of increasing amounts of the wild-type tropomyosin minigene plasmid into HeLa cells results in activation of the skeletal muscle-type splice in nonmuscle cells. HeLa cells were transfected with the wild-type tropomyosin minigene pSV40-2 at the concentrations indicated $10,0.1,1.0$, $2.5,5.0,10$, and $20 \mu \mathrm{g}$ ), or $2 \mu \mathrm{g}$ of the wild-type minigene was cotransfected with a plasmid that expresses $T$ antigen and cytoplasmic RNA harvested $48 \mathrm{hr}$ later. To control for the amount of DNA in each transfection, carrier DNA was adjusted to maintain a total DNA concentration of $20 \mu \mathrm{g}$ per transfection. The schematic diagram of the tropomyosin minigene used and autoradiograph of RNA protection analyses are as described in Fig. 2A. The identity of the band that increases in intensity with increasing amounts of transfected plasmid located just below the $\alpha$-globin protection products likely represents the protection of sequences containing exons $8+9$. The identity of the band detected with the skeletal muscle probe at high concentrations of DNA and in the presence of $\mathrm{T}$ antigen is unknown. (Bottom) Schematic diagram of the structure of the RNA probe and protected fragments (splice products). 


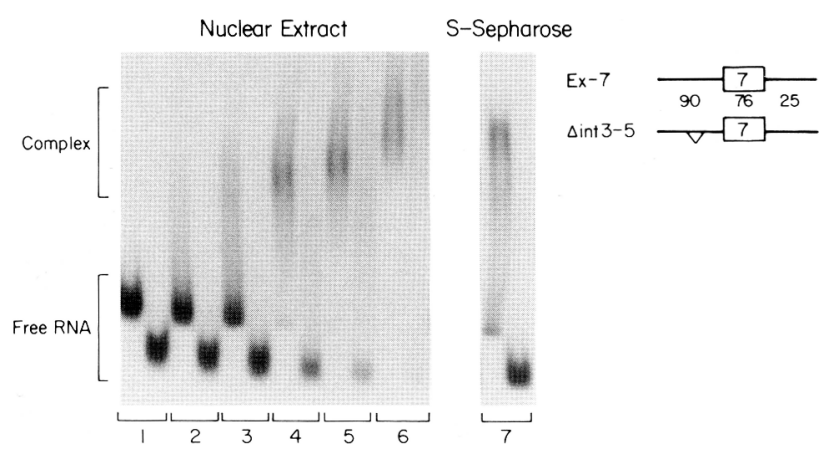

Figure 7. HeLa cell nuclear extracts contain factors that interact with the $3^{\prime}$ end of intron $6 .{ }^{32} \mathrm{P}$-Labeled RNAs were incubated with unfractionated HeLa cell nuclear extracts (lanes 1-6) and fractions from the S-Sepharose column (see Materials and methods), and separated on a denaturing $4 \%$ polyacrylamide gels. Lanes 1-6 contained $0.4,1.0,2,4,8$, and $20 \mu \mathrm{g}$ of protein, respectively. Each concentration of extract was assayed with the wild-type (left) and mutant (right $)^{32}$ P-labeled RNA. The position of the free RNA and complex are indicated at left. A schematic diagram of the structures of the RNA used in the gel mobility-shift assay is shown at right.

cal for the interaction of the RNA with the binding proteins. These results correlate with the in vivo results and suggest that the mutations function in vivo as a result of the inability of the RNA to form a complex with these cellular factors.

To determine the specificity of the interaction of the wild-type Ex-7 RNA with cellular factors we carried out a series of competition experiments using wild-type, mutant, and nonspecific competitors. Wild-type Ex-7 RNA labeled with ${ }^{32} \mathrm{P}$ was assayed in the presence of different competitors, as indicated in Figure 8B. Addition of unlabeled wild-type RNA resulted in a dose-dependent reduction in the formation of the complex (Fig. 8B). In contrast, addition of the other three unlabeled RNAs containing a mutation in the $3^{\prime}$ end of intron 6 (int-3), sequences around exon $6(\mathrm{Ex}-6)$ and exon $8(\mathrm{Ex}-8)$ had no effect on complex formation (Fig. 8B). To study further the region involved in complex formation unlabeled RNAs representing different regions of the wild-type Ex-7 RNA were used as competitors (Fig. 8C). Only the wild-type RNA and RNA-containing sequence in the 3 ' end of intron 6 (WT-3') were able to compete with ${ }^{32} \mathrm{P}$. labeled wild-type probe for complex formation. It is worth noting that the uppermost shift observed with the Ex7-5' competitor at $1000 \mathrm{ng}$ is a result of the formation of an intermolecular hybrid molecule formed between the ${ }^{32} \mathrm{P}$-labeled RNA and the competitor. These results indicate that the intron sequences upstream of the $3^{\prime}$ splice site of exon 7 are critical for complex formation.

\section{Discussion}

The role of RNA secondary structure in alternative splicing of $\beta-T M$ pre-RNA

Previous studies of alternative splicing of the rat and chicken $\beta$-TM genes have suggested that one possible mechanism by which the use of exon 7 is regulated in nonmuscle and skeletal muscle cells is by regulation of RNA secondary structure (Helfman et al. 1988, 1990; Libri et al. 1989, 1990, 1991; D'Orval et al. 1991; see also Fig. 9). Computer analysis of intron sequences upstream and downstream of exon 7 in the rat and chicken genes predicts that these RNA sequences can theoretically form a stable secondary structure that would sequester the $5^{\prime}$ - and $3^{\prime}$ - splice sites of this exon from the splicing machinery and thereby prevents its use in nonmuscle cells. This phylogenetically conserved, putative secondary structure could then be subject to regulation via cellular factors that would either stabilize or destabilize the structure in nonmuscle and skeletal muscle cells, respectively, and thereby lead to the use of this exon in a tissue-specific manner. This model would predict that intron sequences upstream as well as downstream of exon 7 would contain cis-acting elements necessary for regulating the use of exon 7 in nonmuscle cells. However, three sets of experiments presented in this study provide strong evidence against a mechanism based solely on RNA secondary structure. First, the removal of intron sequences downstream of exon 7 did not result in activation of the skeletal muscle exon in nonmuscle cells (Fig. 4). Second, the activation of the skeletal muscle splice observed following the introduction of clustered point mutations in intron 6 and exon 7, which changed as few as three nucleotides in the pre-mRNA, would not be expected to disrupt the extensive secondary structure needed to sequester exon 7 (Figs. 2A and 3). Third, overexpression of the pre-mRNA resulted in activation of the skeletal muscle exon, presumably the result of titration of some inhibitory activity (blocking factors) in nonmuscle cells (Fig. 6). Therefore, on the basis of the considerations given above, it is unlikely that alternative splicing of the rat $\beta$-TM gene will involve the kind of secondary structure proposed for the chicken $\beta$-TM gene (Libri et al. 1990; D'Orval et al. 1991).

Although alternative splicing of the rat $\beta$-TM gene does not appear to require a secondary structure involving intron sequences downstream of exon 7, a more limited structure localized to sequences within exon 7 could be involved in tissue-specific splicing. Both rat and chicken $\beta$-TM genes contain a phylogenetically conserved secondary structure within the skeletal muscle exon (Helfman et al. 1990; Libri et al. 1990, 1991). The sequences contained in exon 7 are able to form a secondary structure, comprised of a stem-loop (Helfman et al. 1990; Libri et al. 1990). Strong evidence that such a structure does exist comes from recent studies of the chicken $\beta$-TM gene (Libri et al. 1991). Using compensatory base substitutions these studies revealed that sequences confined to the skeletal muscle exon were required for regulated alternative splicing and that these sequences function, in part, by a secondary structure (Libri et al. 1991). The results presented in this paper also demonstrate that similar sequences contained within exon 7 of the rat $\beta$-TM gene function in splice-site selection (Fig. 3). In addition, the mutations that showed the strongest activation of the skeletal muscle exon, that 

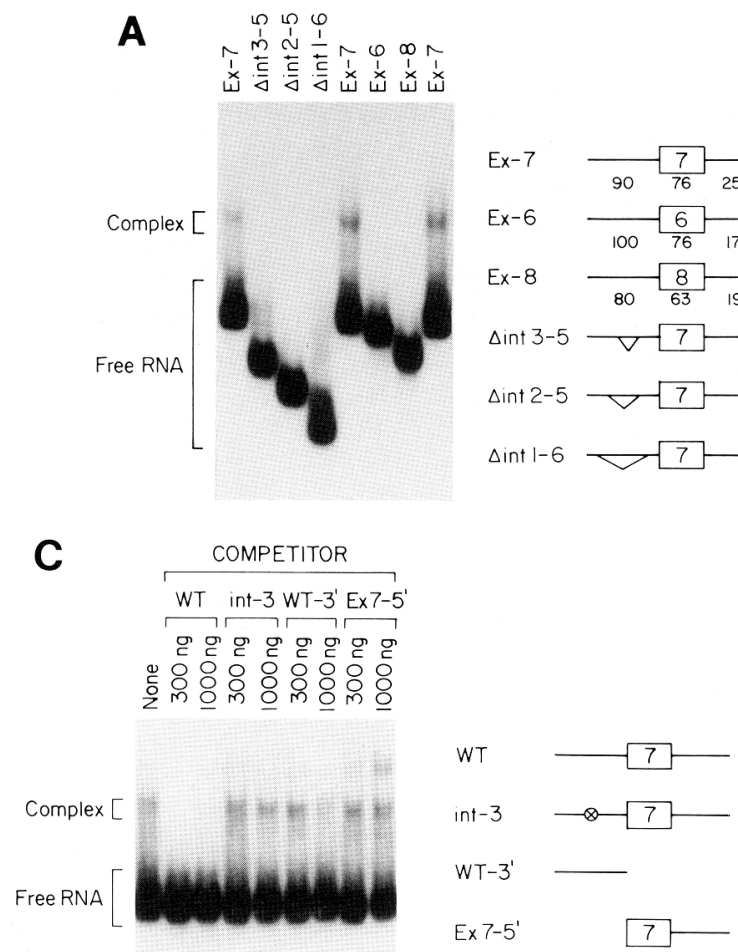
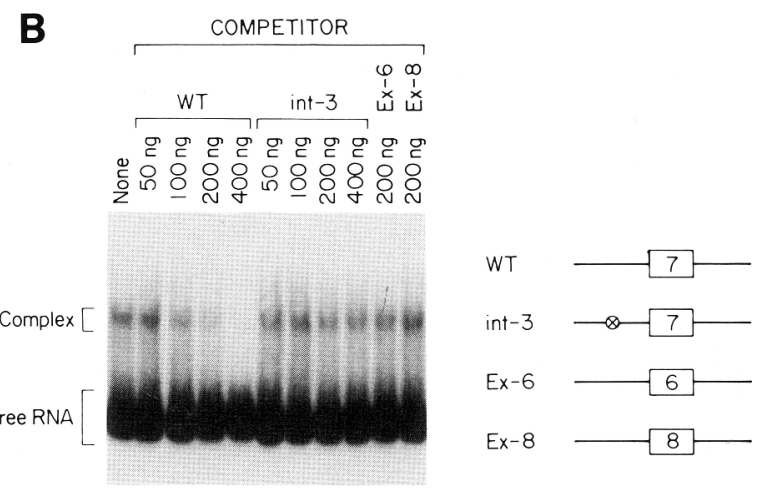

plex are indicated at left $;$ a schematic $d$ at right. $(C)$ Competition experiments showing that the $3^{\prime}$ end of intron 6 contains sequences important for binding. Binding reactions were carried out by using ${ }^{32} \mathrm{P}$-labeled Ex-7 RNA (see $A$ ). The ${ }^{32} \mathrm{P}$-labeled RNAs were incubated with fractions from the S-Sepharose column (see Materials and methods) in the presence of wild-type, int-3, WT-3', and Ex7-5', unlabeled competitor RNAs at the concentrations indicated and separated on a denaturing $4 \%$ polyacrylamide gel. The positions of the free RNA and complex are indicated at left; a schematic diagram of the structures of the competitor RNAs used in the gel mobility-shift assay is shown at right.

is, Ex-1 (Fig. 3), would disrupt the stem of the predicted RNA structure. Thus, a secondary structure localized to those sequences within the skeletal muscle exon likely plays a role in regulated alternative splice-site selection.

The role of distant branch sites in alternative splice-site selection

Branch sites located an unusually long distance from a 3 '-splice site (i.e., $>40$ nucleotides) are a general feature of some alternatively excised introns and function in at least two ways in alternative splice-site selection. The best-studied examples involve the rat $\alpha$-TM gene and the rat and the chicken $\beta$-TM genes (Helfman et al. 1989, 1990; Smith and Nadal-Ginard 1989; Goux-Pelletan 1990; Libri et al. 1990; Mullen et al. 1991; this study). In the case of the rat $\alpha$-TM gene, the use of a distant branch site plays a direct role in preventing the splicing together of the two mutually exclusive exons 2 and 3 (Smith and Nadal-Ginard 1989). These two exons are never spliced together in any cell type. The molecular basis for this is the proximity of the $5^{\prime}$-splice site of exon 2 relative to the branchpoint used for exon 3 , which is only 42 nucleotides apart. In contrast, this mechanism cannot explain the mutually exclusive use of exons 6 and 7 in the rat and chicken $\beta$-TM genes, because the $5^{\prime}$-splice site of exon 6 in these genes is located at least 136 nucleotides upstream of the branchpoints used for the skeletal muscle exon (Helfman et al. 1989, 1990; Goux-Pelletan et al. 1990 ). Thus, the distant branchpoints of the $\beta$-TM genes in rat and chicken play a different role in alternative splicing. It is clear from this and previous studies that intron sequences located between the branchpoint and downstream $3^{\prime}$-splice site contain important information for splice-site selection because deletion or mutation of these sequences results in the use of the skeletal muscle exon in nonmuscle cells (Helfman et al. 1990; Libri et al. 1990; this study). These sequences appear to function by providing a binding site for cellular factors that regulate tissue-specific splicing (see below).

\section{Cellular factors involved in alternative splice-site selection}

The in vitro binding studies show that intron sequences upstream of exon 7 bind specifically to cellular factors (Figs. 7 and 8). Although the nature of these factors, the mechanism of their action, and a precise definition of the sequences in the pre-mRNA that they bind to remains to be determined, it is clear from our studies that the bind- 


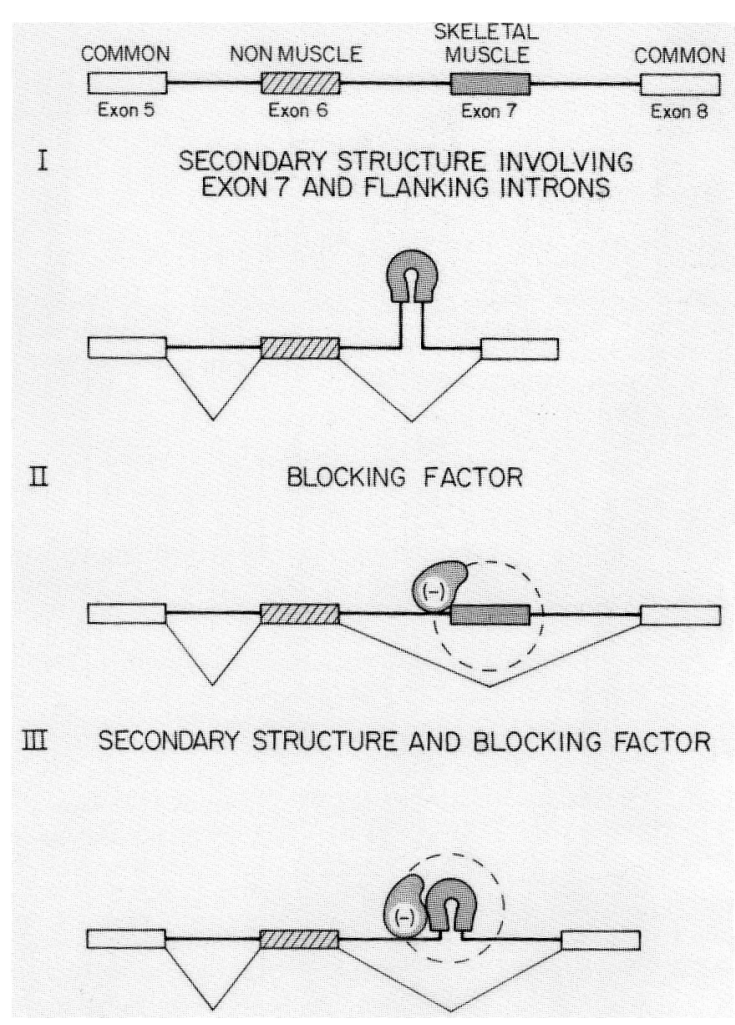

Figure 9. Possible mechanisms by which exon 7 is excluded in nonmuscle cells (for explanation see, Discussion).

ing sites of these factors correlate with sequences required to prevent the use of the skeletal muscle splice in nonmuscle cells. Although we found that clustered point mutations in the $3^{\prime}$ end of intron 6 resulted in use of the skeletal muscle-type splice in nonmuscle cells, no single mutation of this type was able to completely activate the use of exon 7, that is, there was still use of exon 6 (Fig. 2A). This is in contrast to the deletions that lead to complete use of exon 7 (Fig. 2B; Helfman et al. 1990). In addition, these mutations in the $3^{\prime}$ end of intron 6 are located over a stretch of at least 40 nucleotides. These results would suggest that either a single factor binds to multiple sites on the pre-mRNA or multiple factors bind to multiple sites on the pre-mRNA. We have observed that the $3^{\prime}$ end of intron 6 in the rat $\beta$-TM gene contains seven overlapping copies of an 11-nucleotide imperfect repeat, with the sequence $\mathrm{YR}(\mathrm{Y})_{4} \mathrm{R}(\mathrm{Y})_{2} \mathrm{RY}[(\mathrm{Y})$, pyrimidine; ( $R$ ) purine] (Fig. 1). Interestingly, the locations of the four repeats correspond to the position of the four clustered point mutations (int- 2 , int -3 , int -4 , and int-5) that resulted in the use of exon 7 in nonmuscle cells (Fig. 2B). Whether or not the repeats in the tropomyosin gene represent true binding sites for cellular factors is currently being studied. Recently, six copies of a 13-nucleotide imperfect repeat was identified in the pre-mRNA of the dsx gene of Drosophila melanogaster and is required for binding specifically to the tra-2 protein (Hedley and Maniatis 1991).
It remains to be determined whether the cellular factors identified in this study bind to a linear RNA molecule or whether they recognize RNA secondary structure (Fig. 9). As discussed above, although it is unlikely that an extensive secondary structure prevents the use of exon 7 in nonmuscle cells, a local secondary structure within exon 7 could provide a binding site for factors (Fig. 9). For example, the binding of the HIV rev protein to the rev-response elements requires a secondary structure (Olsen et al. 1990). It is worth noting that none of the clustered point mutations in exon 7 affected the binding of the RNA to the factors identified in the present studies (data not shown). These results suggest that a factor bound to the intron might also bind to the exon or that a different factor might interact with the exon sequences. Thus, it remains to be determined whether the intron and exon mutations act via the same mechanism and cellular factors.

\section{Mechanisms of alternative splice-site selection}

The mechanism by which factors binding to the premRNA block the use of exon 7 in nonmuscle cells remains to be elucidated. One possibility is that the binding of factors to the RNA results in the formation of a ribonucleoprotein (RNP) structure, which prevents the interaction of splicing factors with the $5^{\prime}$ - and $3^{\prime}$-splice sites of exon 7. Alternatively, individual general splicing factors such as U1 small nuclear RNP (snRNP), U2 snRNP, U2AF (Zamore and Green 1989), and ASF/SF2 could be targets for the actions of a blocking factor. Thus, a blocking factor bound to the RNA might prevent the interaction of general splicing factors with the premRNA and thereby inhibit the use of a particular splice site. Because ASF/SF2 affects the use of $5^{\prime}$-splice sites (Ge and Manley 1990; Krainer et al. 1990a), it is possible that the action of this splicing factor might also be subject to regulation by factors that antagonize its functions. A major determinant in splice-site strength is the pyrimidine content adjacent to the branchpoint sequences; the longer the pyrimidine tract, the more favorable the splice is (Mullen et al. 1991). Although exon 7 contains a lengthy polypyrimidine tract associated with the use of its $3^{\prime}$-splice site, it is normally not used in nonmuscle cells. A polypyrimidine tract-binding protein has been identified, whose binding correlates with the relative use of a 3'-splice site (Garcia-Blanco et al. 1989; Mullen et al. 1991). The interaction of this polypyrimidine tract-binding protein could also be involved in regulated alternative splice-site selection.

Whether or not the factors identified in this study are expressed in a tissue-specific manner remains to be determined. For example, one prediction from this study would be that in skeletal muscle these blocking factors are no longer expressed or become inactivated. In the absence of functional blocking factors the skeletal muscle exon would become the default splice choice. The long polypyrimidine tract associated with the 3 '-splice site of exon 7 may be sufficient, in the absence of blocking factors, to allow exon 7 to become the "default" 
splice choice, simply the result of the more competitive nature of the adjacent $3^{\prime}$-splice site relative to exon 6 . Support for this model comes from experiments showing that mutations in the $3^{\prime}$ end of intron 6 can lead to exclusive use of the skeletal muscle splice in nonmuscle cells (Helfman et al. 1990; this study). On the other hand, recent work on ASF/SF2, showing that concentrations of a single factor can effect the use of alternative splice sites, raises the possibility that alternative splicing could, in principle, arise by changes in the relative concentrations of various factors (Ge and Manley 1990; Krainer et al. 1990a). Thus, differences in the relative concentrations of the factors identified in this study could be responsible for regulated alternative splicing. Finally, additional factors might be required for regulation. For example, the factors identified in the present studies once bound to the pre-mRNA might then bind to other cellular factors that modulate the use of exon 7 in a tissue-specific manner.

In summary, having identified cellular factors that interact with specific sequences in the pre-mRNA we can now direct our efforts to a greater understanding of how these factors act to regulate alternative splicing. Work is in progress to purify the factor(s) that interact with the RNA, to precisely identify the sequences to which they bind, and to develop in vitro assays to identify their function.

\section{Materials and methods}

\section{Plasmid constructions}

For studies designed to analyze the internal alternatively spliced region of the rat $\beta$-TM gene in vivo plasmids pSV40-p2 were used (Helfman et al. 1988). The indicated mutations were subcloned into plasmid pSV40-p2. In all transfection studies HeLa cells were cotransfected with an $\alpha$-globin test gene (Treisman et al. 1983; Herr and Clarke 1986).

The DNA templates for use in in vitro transcription are derived from the rat $\beta$-TM gene (Helfman et al. 1986). The sequences of all mutations were determined by DNA sequence analysis (Sanger et al. 1977) and are shown in Figure 1.

\section{Oligonucleotide site-directed mutagenesis}

Clustered point mutations, which introduced a $\mathrm{BamHI}$ site in the DNA, were introduced into intron 6 and exon 7 by oligonucleotide mutagenesis (Kunkel 1985). Mutations in the 5' GU dinucleotide and 3 '-splice site AG dinucleotide of exon 6 were also introduced by the method of Kunkel (1985). The mutations were confirmed by sequencing the DNA (Sanger et al. 1977).

\section{Nuclear extract and fractionation}

Sonicated and double-extracted nuclear extracts were prepared as described previously starting with 8 liters of HeLa cells that were grown to a density of $1 \times 10^{6} /$ liter (Krainer et al. 1990b). All steps were carried out at $4^{\circ} \mathrm{C}$. The nuclear extract material was dialyzed against buffer D ([20 mm HEPES (pH 8.0), $100 \mathrm{~mm}$ $\mathrm{KCl}, 0.2 \mathrm{~mm}$ EDTA, $0.5 \mathrm{~mm}$ DTT, $5 \%$ glycerol]). The nuclear extract was brought to $20 \%$ ammonium sulfate by the addition of solid ammonium sulfate $(10.6 \mathrm{~g} / 100 \mathrm{ml})$. The solution was stirred gently for $30 \mathrm{~min}$ and centrifuged for $30 \mathrm{~min}$ at $2300 \mathrm{~g}$ to remove the precipitated was proteins. The supernatant was brought to $50 \%$ ammonium sulfate by the addition of solid ammonium sulfate $(17.5 \mathrm{~g} / 100 \mathrm{ml})$. The solution was stirred gently for $30 \mathrm{~min}$ and the precipitate was recovered by centrifugation for $30 \mathrm{~min}$ at $2300 \mathrm{~g}$. This $20-50 \%$ ammonium sulfate pellet was resuspended in buffer containing $20 \mathrm{mM}$ HEPES $\mid \mathrm{pH}$ 8.0 ), $100 \mathrm{~mm} \mathrm{KCl}, 2 \mathrm{~mm}$ EDTA, $5 \%$ glycerol, $0.02 \% \mathrm{NP}-40,0.5$ $\mathrm{mM}$ DTT, and $0.5 \mathrm{~mm}$ PMSF. The protein concentration was adjusted in the same buffer to $4 \mathrm{mg} / \mathrm{ml}$ and loaded on a Whatman P11 phosphocellulose column $(15 \times 1.5 \mathrm{~cm})$. The column was washed with $30 \mathrm{ml}$ of buffer D and then eluted stepwise in buffer D containing $150 \mathrm{~mm}, 350 \mathrm{~mm}$, and $1000 \mathrm{~mm} \mathrm{KCl}$. Each step was collected in $6 \times 5$-ml fractions. Each fraction from the wash, $150 \mathrm{~mm}, 350 \mathrm{~mm}$, and $1000 \mathrm{~mm} \mathrm{KCl}$ elutions, was collected and assayed for RNA-binding proteins. Most of the binding activity was found in the $350 \mathrm{mM} \mathrm{KCl}$ fraction. The material from this fraction was adjusted to $100 \mathrm{mM} \mathrm{KCl}$ and loaded onto a $10-\mathrm{ml}$ Pharmacia S-Sepharose column. The column was washed with $30 \mathrm{ml}$ of buffer D and eluted stepwise in buffer D containing $150 \mathrm{mM}, 300 \mathrm{mM}$, and $500 \mathrm{~mm} \mathrm{KCl}$. Each step was collected in $4 \times 5$ - $\mathrm{ml}$ fractions. Each fraction from the wash, $150 \mathrm{mM}, 300 \mathrm{~mm}$, and $500 \mathrm{~mm} \mathrm{KCl}$ elutions, was collected and assayed for RNA-binding proteins. The majority of the RNAbinding activity was found in the $150 \mathrm{~mm}$ elution and was used for further characterization.

\section{RNA mobility-shift assay}

The RNA mobility-shift assays were performed essentially according to Konarska and Sharp (1986). The ${ }^{32}$ P-labeled SP6/ tropomyosin transcripts were synthesized in vitro primed with CAP analog as described (Konarska et al. 1984). The ${ }^{32}$ P-labeled pre-mRNAs were further purified on acrylamide/urea gels. The protein-RNA complexes were separated by native gel electrophoresis using $4 \%$ acrylamide gels (acrylamide/bis, 29:1) by using TBE (89 $\mathrm{mm}$ Tris base, $89 \mathrm{~mm}$ boric acid, 2 mM EDTA) as a running buffer. The gels $(25 \times 0.15 \mathrm{~cm})$ were pre-electrophoresed at $10 \mathrm{~V} / \mathrm{cm}$ for $1 \mathrm{hr}$ prior to loading samples. Binding reactions were performed in a $25-\mu \mathrm{l}$ reaction containing, $20 \mathrm{mM}$ HEPES ( $\mathrm{pH} 8.0$ ), $5 \%$ glycerol, $70 \mathrm{~mm} \mathrm{KCl,} 3 \mathrm{~mm} \mathrm{MgCl}$, 3 units of RNasin, $1 \mu \mathrm{g}$ of tRNA, $0.5 \mathrm{~mm}$ ATP, $20 \mathrm{~mm}$ creatine phosphate, $5-20 \mu \mathrm{g}$ of protein, and uniformly ${ }^{32} \mathrm{P}$-labeled RNA probe. After $30 \mathrm{~min}$ of incubation at $30^{\circ} \mathrm{C}$, the sample was adjusted to $5 \mathrm{mg} / \mathrm{ml}$ with heparin and incubated at $30^{\circ} \mathrm{C}$ for 10 min. One microliter of loading buffer containing $97 \%$ glycerol and $0.01 \%$ bromphenol blue plus $0.01 \%$ xylene cyanol was added just before loading the sample on the gel. The gel was electrophoresed at room temperature at $10 \mathrm{~V} / \mathrm{cm}$ until the $x y$ lene cyanol had migrated $12-13 \mathrm{~cm}$. The gels were dried and visualized by autoradiography.

\section{Transfections and RNA analysis}

HeLa cells were grown in Dulbecco's modified Eagle medium (DMEM) supplemented with $10 \%$ fetal bovine serum (FBS). Unless otherwise indicated, HeLa cells were transfected with $5 \mu \mathrm{g}$ of tropomyosin plasmid DNA and $1 \mu \mathrm{g}$ of $\alpha$-globin test plasmid (Treisman et al. 1983) per 100- mm plate by using a calcium phosphate coprecipitation procedure; cells were harvested $48 \mathrm{hr}$ later, and the cytoplasmic RNA was isolated as described previously (Helfman et al. 1988, 1990). The $\alpha$-globin plasmid served as an internal control for transformation efficiency. RNase protection assays were carried out as described (Zinn et al. 1983). The plasmids used for synthesis of ${ }^{32} \mathrm{P}$-labeled antisense RNA were derived from cDNA clones encoding rat fibroblast TM-1 
Guo et al.

and skeletal muscle $\beta$-TM and have been described elsewhere (Helfman et al. 1988, 1990).

\section{Acknowledgments}

We thank J.D. Watson for his enthusiastic support and encouragement of this work. Special thanks go to Laura Berkowitz, David Frendewey, Nouria Hernandez, Adrian Krainer, and Rich Roberts for helpful discussions and critical reading of this manuscript. We also acknowledge Philip Renna, Jim Duffy, and Madeline Wisnewski for help with the preparation of this manuscript. D.M.H. is the recipient of grants GM43049 and CA46370 from the National Institutes of Health and a grant from the Muscular Dystrophy Association, and is an Established Investigator of the American Heart Association.

The publication costs of this article were defrayed in part by payment of page charges. This article must therefore be hereby marked "advertisement" in accordance with 18 USC section 1734 solely to indicate this fact.

\section{References}

Black, D.L. 1991. Does steric interference between splice sites block the splicing of a short c-src neuron-specific exon in non-neuronal cells? Genes \& Dev. 5: 389-402.

Cooper, T.A. and C.P. Ordahl. 1989. Nucleotide substitutions within the cardiac troponin $\mathrm{T}$ alternative exon disrupt premRNA alternative splicing. Nucleic Acids Res. 17: 79057921.

D'Orval, B.C., Y.D. Carafa, P. Sirand-Pugnet, M. Gallego, E. Brody, and J. Marie. 1991. RNA secondary structure repression of a muscle-specific exon in HeLa cell nuclear extracts. Science 252: 1823-1828.

Fu, X-Y. and J.L. Manley. 1987. Factors influencing alternative splice site utilization in vivo. Mol. Cell. Biol. 7: 738-748.

Fu, X-Y., H. Ge, and J.L. Manley. 1988. The role of the polypyrimidine stretch at the SV40 early pre-mRNA 3 ' splice site in alternative splicing. EMBO $/$. 7: 809-817.

Garcia-Blanco, M.A., S.F. Jamison, and P.A. Sharp. 1989. Identification and purification of a 62,000-dalton protein that binds specifically to the polypyrimidine tract of introns. Genes \& Dev. 3: 1874-1886.

Gattoni, R., P. Schmitt, and J. Stevenin. 1988. In vitro splicing of adenovirus E1A transcripts: characterization of novel reactions and of multiple branch points abnormally far from the 3' splice site. Nucleic Acids Res. 16: 2389-2409.

Ge, H. and J.L. Manley. 1990. A protein factor, ASF, controls cell-specific alternative splicing of SV40 early pre-mRNA in vitro. Cell 62: 25-34.

Goux-Pelletan, M.D., D. Libri, Y. DiAubenton-Carafa, M. Fiszman, E. Brody, and J. Marie. 1990. In vitro splicing of mutually exclusive exons from the chicken beta-tropomyosin role: Role of the branch point location and very long pyrimidine stretch. $E M B O$ I. 9: 241-249.

Green, M.R. 1986. Pre-mRNA splicing. Annu. Rev. Genet. 20: $671-708$.

Hampson, R.K., L.L. Follette, and F.M. Rottman. 1989. Alternative processing of bovine growth hormone mRNA is influenced by downstream exon sequences. Mol. Cell. Biol. 9: 1604-1610.

Hedley, M.L. and T. Maniatis. 1991. Sex-specific splicing and polyadenylation of $d s x$ pre-mRNA requires a sequence that binds specifically to tra-2 protein in vitro. Cell 65: $579-586$.

Helfman, D.M. and W.M. Ricci. 1989. Branch point selection in alternative splicing of tropomyosin pre-mRNAs. Nucleic
Acids. Res. 17: 5633-5650.

Helfman, D.M., S. Cheley, E. Kuismanen, L.A. Finn, and Y. Yamawaki-Kataoka. 1986. Nonmuscle and muscle tropomyosin isoforms are expressed from a single gene by alternative RNA splicing and polyadenylation. Mol. Cell. Biol. 6: 35823595.

Helfman, D.M., W.M. Ricci, and L.A. Finn. 1988. Alternative splicing of tropomyosin pre-mRNAs in vitro and in vivo. Genes \& Dev. 2: 1627-1638.

Helfman, D.M., R.F. Roscigno, G.J. Mulligan, L.A. Finn, and K.S. Weber. 1990. Identification of two distinct intron elements involved in alternative splicing of $\boldsymbol{\beta}$-tropomyosin premRNA. Genes \& Dev. 4: 98-110.

Herr, W. and J. Clarke. 1986. The SV40 enhancer is composed of multiple functional elements that can compensate for one another. Cell 45: 4610-470.

Konarska, M.M. and P.A. Sharp. 1986. Electrophoretic separation of complexes involved in the splicing of precursors to mRNAs. Cell 46: 845-855.

Konarska, M.M., R.A. Padgett, and P.A. Sharp. 1984. Recognition of cap structure in splicing in vitro mRNA precursors. Cell 38: 731-736.

Krainer, A.R., G.C. Conway, and D. Kozak. 1990a. The essential pre-mRNA splicing factor SF2 influences 5 ' splice site selection by activating proximal sites. Cell 62: 35-42.

- 1990b. Purification and characterization of pre-mRNA splicing factor SF2 from HeLa cells. Genes \& Dev. 4: 11581171.

Kunkel, T.A. 1985. Rapid and efficient site-specific mutagenesis without phenotypic selection. Proc. Natl. Acad. Sci. 82: 488-492.

Kuo, H.-C., F.-U.H. Nasim, and P.J. Grabowski. 1991. Control of alternative splicing by the differential binding of U1 small nuclear ribonucleoprotein particle. Science 251: 1045-1050.

Lees-Miller, J.P. and D.M. Helfman. 1991. The molecular basis for tropomyosin isoform diversity. BioEssays 13: 429-437.

Libri, D., M. Lemonnier, T. Meinnel, and M.Y. Fiszman. 1989. A single gene codes for the beta subunits of smooth and skeletal muscle tropomyosin in the chicken. J. Biol. Chem. 264: 2935-2944.

Libri, D., M. Goux-Pelletan, E. Brody, and M.Y. Fiszman. 1990. Exon as well as intron sequences are cis-elements for the mutually exclusive alternative splicing of the $\beta$-tropomyosin gene. Mol. Cell. Biol. 10: 5036-5046.

Libri, D., A. Piseri, and M.Y. Fiszman. 1991. Tissue-specific splicing in vivo of the $\beta$-tropomyosin gene: Dependence on an RNA secondary structure. Science 252: 1842-1845.

Maniatis, T. 1991. Mechanisms of alternative pre-mRNA splicing. Science 251: 33-34.

Mardon, H.J., G. Sebastio, and F.E. Baralle. 1987. A role for exon sequences in alternative splicing of the human fibronectin gene. Nucleic Acids. Res. 15: 7725-7733.

McKeown, M. 1990. Regulation of alternative splicing. Genet. Eng. 12: 139-181.

Mullen, M.P., C.W.J. Smith, J.G. Patton, and B. Nadal-Ginard. 1991. $\alpha$-Tropomyosin mutually exclusive exon selection: Competition between branchpoint/polypyrimidine tracts determines default exon choice. Genes \& Dev. 5: 642-655.

Noble, J.C.S., Z.-Q. Pan, C. Prives, and J.L. Manley. 1987. Splicing of SV40 early pre-mRNA to large $T$ and small $t$ mRNAs utilizes different patterns of lariat branch sites. Cell 50: 227236.

Noble, J.C.S., C. Prives, J.L. Manley. 1988. Alternative splicing of SV40 early pre-mRNA is determined by branch site selection. Genes \& Dev. 2: 1460-1475.

Olsen, H.S., P. Nelbock, A.W. Cochrane, and C.A. Rosen. 1990. 
Secondary structure is the major determinant for interaction of HIV rev protein with RNA. Science 247: 845-848.

Reed, R. and T. Maniatis. 1986. A role for exon sequences and splice-site proximity in splice-site selection. Cell 46: 681690.

1988. The role of the mammalian branchpoint sequence in pre-mRNA splicing. Genes \& Dev. 2: 1268-1276.

Sanger, F., S. Nicklen, and A.R. Coulson. 1977. DNA sequencing with chain-terminating inhibitors. Proc. Natl. Acad. Sci. 74: 5463-5467.

Smith, C.W.J. and B. Nadal-Ginard. 1989. Mutually exclusive splicing of alpha-tropomyosin exons enforced by an unusual lariat branch point location: implications for constitutive splicing. Cell 56: 749-758.

Smith, C.W.J., J.G. Patton, and B. Nadal-Ginard. 1989. Alternative splicing in the control of gene expression. Annu. Rev. Genet. 23: 527-577.

Somasekhar, M.B. and J.E. Mertz. 1985. Exon mutations that affect the choice of splice sites used in processing the SV40 late transcripts. Nucleic Acids Res. 13: 5591-5609.

Streuli, M. and H. Saito. 1989. Regulation of tissue-specific alternative splicing: Exon-specific cis-elements govern the splicing of leukocyte common antigene pre-mRNA. $E M B O$ J. 3: 787-796.

Treisman, R., M.R. Green, and T. Maniatis. 1983. Cis and trans activation of globin gene transcription in transient assays. Proc. Natl. Acad. Sci. 80: 7428-7432.

Zamore, P.D. and M.R. Green. 1989. Identification, purification, and biochemical characterization of U2 small nuclear riboprotein auxilary factor. Proc. Natl. Acad. Sci. 86: 92439247.

Zhuang, Z., H. Leung, and A. Weiner. 1987. The natural $5^{\prime}$ splice site of simian virus 40 large $T$ antigen can be improved by increasing the base complementarity to U1 RNA. Mol. Cell. Biol. 7: 3018-3020.

Zhuang, Y., A.M. Goldstein, and A.M. Weiner. 1989. UACUAAC is the preferred branch site for mammalian mRNA splicing. Proc. Natl. Acad. Sci. 86: 2752-2756.

Zinn, K., D. DiMaio, and T. Maniatis. 1983. Identification of two distinct regulatory regions adjacent to the human betainterferon gene. Cell 34: 865-879. 


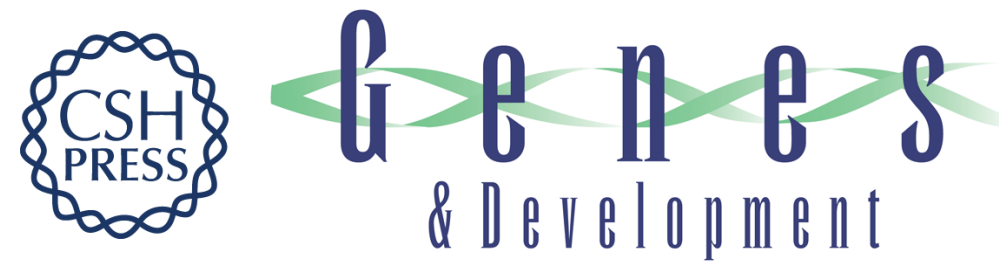

\section{Alternative splicing of beta-tropomyosin pre-mRNA: cis-acting elements and cellular factors that block the use of a skeletal muscle exon in nonmuscle cells.}

W Guo, G J Mulligan, S Wormsley, et al.

Genes Dev. 1991, 5:

Access the most recent version at doi:10.1101/gad.5.11.2096

References This article cites 46 articles, 24 of which can be accessed free at:

http://genesdev.cshlp.org/content/5/11/2096.full.html\#ref-list-1

License

Email Alerting Service

Receive free email alerts when new articles cite this article - sign up in the box at the top right corner of the article or click here.

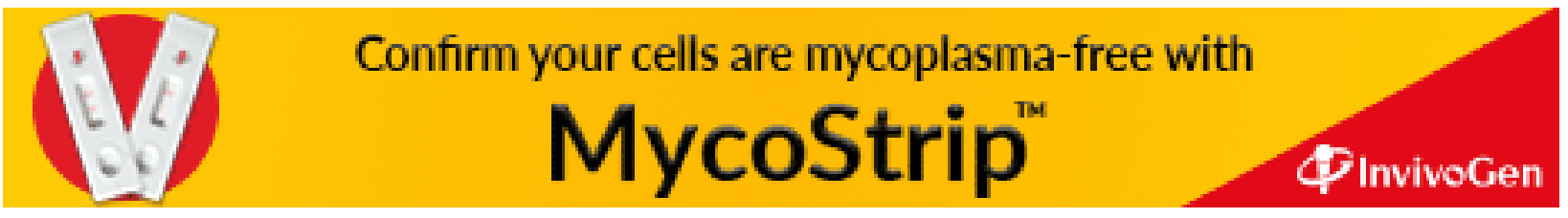

